Article

\title{
Phylogenetically Diverse Fusarium Species Associated with Sorghum (Sorghum Bicolor L. Moench) and Finger Millet (Eleusine Coracana L. Garten) Grains from Ethiopia
}

\author{
Alemayehu Chala ${ }^{1, *}$, Tulu Degefu ${ }^{2}$ and May Bente Brurberg ${ }^{3,4}$ \\ 1 College of Agriculture, Hawassa University, P.O. Box 05, Hawassa 1000, Ethiopia \\ 2 International Crops Research Institute for the Semi-Arid Tropics, P.O. Box 5689, Addis Ababa 1000, Ethiopia; \\ tukanovic97@yahoo.com \\ 3 Department of Plant Sciences, Norwegian University of Life Sciences, P.O. Box 5003, Ås NO-1432, Norway; \\ may.brurberg@nibio.no \\ 4 Division of Biotechnology and Plant Health, Norwegian Institute of Bioeconomy Research (NIBIO), \\ Høgskoleveien 7, Ås N-1432, Norway \\ * Correspondence: alemayehuchala@yahoo.com; Tel.: +251-912-163096; Fax: +251-46-2206711
}

Received: 15 May 2019; Accepted: 13 June 2019; Published: 15 June 2019

\begin{abstract}
Fusarium is one of the most diverse fungal genera affecting several crops around the world. This study describes the phylogeny of Fusarium species associated with grains of sorghum and finger millet from different parts of Ethiopia. Forty-two sorghum and 34 finger millet grain samples were mycologically analysed. All of the sorghum and more than $40 \%$ of the finger millet grain samples were contaminated by the Fusarium species. The Fusarium load was higher in sorghum grains than that in finger millet grains. In addition, 67 test isolates were phylogenetically analysed using $E F-1 \alpha$ and $\beta$-tubulin gene primers. Results revealed the presence of eight phylogenetic placements within the genus Fusarium, where 22 of the isolates showed a close phylogenetic relation to the F. incarnatum-equiseti species complex. Nevertheless, they possess a distinct shape of apical cells of macroconidia, justifying the presence of new species within the Fusarium genus. The new species was the most dominant, represented by $33 \%$ of the test isolates. The current work can be seen as an important addition to the knowledge of the biodiversity of fungal species that exists within the Fusarium genus. It also reports a previously unknown Fusarium species that needs to be investigated further for toxin production potential.
\end{abstract}

Keywords: beta-tubulin gene; DNA sequence; elongation factor gene (EF1- $\alpha)$; species diversity

\section{Introduction}

The genus Fusarium is one of the most diverse fungal pathogens of plants and animals, including human beings. Fungi that belong to this genus are considered to be among the most harmful pathogens of cultural plants all over the world [1]. In addition to causing substantial yield and quality reduction on crop plants $[2,3]$, members of this genus are also known as producers of important mycotoxins that affect the health of human beings and animals alike [4-6]. Fusarium species are widely distributed across the world, inhabiting the majority of bioclimatic regions and ecosystems [7,8]. The ability of Fusarium spp. to survive under diverse environmental conditions and their potential to infect a wide array of plants, both in natural and managed ecosystems, have contributed a great deal to attaining an immense diversity within the genus. As a result, Fusarium is known as the single most important toxigenic fungi with a confusing and unstable taxonomic history [9]. Many studies that aim to characterize 
fungal population structures, including that of the genus Fusarium, largely depended on conserved homologues genes [10]. Nowadays, there is an increased interest to utilize multilocus approaches to assess population structures of fungi, including that of Fusarium spp. [11-14].Since the early report in 1935 [15], much research has been conducted to resolve the diversity of the genus Fusarium, including phylogenetic relationships between and within species. On the other hand, research on Fusarium spp. from sorghum has been given only peripheral importance until recently [16], while those from millets are largely ignored. As a result, the diversity and population structure of Fusarium spp. associated with sorghum and finger millets is poorly understood. Yet the two crops are important parts of production systems and daily diet for millions of people around the world, especially in the resource-poor drylands of tropical Africa and Asia.

In Ethiopia alone, 4,219,257.2 metric tons of sorghum was harvested from about 1,854,710.93 hectares of land, making it the fourth and third important cereal in total production and area coverage, respectively, [17]. On the other hand, 940,246.3 metric tons of finger millet grains were harvested from 465,508 hectares of land, and this made the crop the sixth most important cereal in Ethiopia [17]. All the sorghum and finger millets are produced, stored, and sold by subsistence farmers.

Toxigenic fungi and associated mycotoxins are reported from sorghum and finger millet grains in Ethiopia by some (rather limited) previous works [18-22]. However, the identity and diversity of Fusarium spp. infecting sorghum and finger millet grains are not yet ascertained. Hence, the current work was conducted with the objective to unravel the genetic diversity of the genus Fusarium, associated with the two crops in Ethiopia. Results of this work would help to better understand the phylogeny and evolutionary relationship of members of this important pathogenic and toxigenic fungus, as the country is one of the major centers of origin and diversity for the two crops.

\section{Materials and Methods}

\subsection{Isolate Collection}

A total of 76 (42 sorghum and 34 finger millet) grain samples that were meant for household consumption and sale on the local markets were collected from farmers' stores in five districts of Northwest, Central, and South Ethiopia (Table 1). Sample collection districts are known producers of the two crops but they were largely ignored by previous studies in the field of toxigenic fungi. Samples ( $1 \mathrm{~kg}$ each) were properly labeled with the name of the location and GPS coordinates, and stored at $4{ }^{\circ} \mathrm{C}$ until isolation.

Table 1. Geographic origin of Fusarium isolates.

\begin{tabular}{cccccc}
\hline \multirow{2}{*}{ Geographic Location } & \multicolumn{2}{c}{ No. of Samples Collected } & \multirow{2}{*}{ Altitude (m) } & \multirow{2}{*}{ Latitude } & \multirow{2}{*}{ Longitude } \\
\cline { 2 - 5 } & Sorghum & Finger Millet & & & \\
\hline South & 16 & 5 & $1297-1590$ & $5^{\circ} 19^{\prime}-5^{\circ} 42^{\prime}$ & $37^{\circ} 22^{\prime}-37^{\circ} 27^{\prime}$ \\
Central & 6 & 9 & $1846-1915$ & $7^{\circ} 18^{\prime}-7^{\circ} 24^{\prime}$ & $38^{\circ} 38^{\prime}-38^{\circ} 40^{\prime}$ \\
Northwest & 20 & 20 & $1054-1465$ & $11^{\circ} 04^{\prime}-11^{\circ} 19^{\prime}$ & $36^{\circ} 20^{\prime}-36^{\circ} 25^{\prime}$ \\
Total & 42 & 34 & & & \\
\hline
\end{tabular}

\subsection{Isolation, Identification, and Storage of the Isolates}

Grain samples were surface-sterilized using $1 \%$ sodium hypochlorite $(\mathrm{NaOCl})$ solution for $90 \mathrm{~s}$, and rinsed three times in sterile, distilled water. The surface-sterilized grains were placed on potato dextrose agar (PDA) and incubated at $25^{\circ} \mathrm{C}$ under continuous fluorescent light for 10 days. After 10 days of incubation, sporulation was observed in the PDA plates. Isolates were tentatively identified as fusaria, based on pigmentation and conidial shape [23]. For confirmation, each isolate was transferred to Spezieller Nährstoffarmer Agar (SNA) plates, incubated under $12 \mathrm{~h}$ light-dark cycles with UV and daylight color fluorescent lights at $25^{\circ} \mathrm{C}$, and the shapes of macroconidia were assessed after 15 days. Pure cultures of each Fusarium isolate were maintained on PDA and stored at $4{ }^{\circ} \mathrm{C}$ as stock cultures. 


\subsection{Grain Contamination by Fusarium Species}

The number of colony-forming units (CFU) of Fusarium species per gram of grain was determined as follows [19]: Ten grams of each sample was surface-sterilized by a quick rinse in $70 \%$ isopropanol and soaked for 1-2 min in 1\% sodium hypochlorite solution. The samples were ground in $90 \mathrm{~mL}$ of saline solution (composed of $0.58 \mathrm{~g} \mathrm{NH}_{2} \mathrm{PO}_{4}, 4 \mathrm{~g} \mathrm{NaCl}$, and $2.6 \mathrm{~g} \mathrm{Na}_{2} \mathrm{HPO}_{4}$ in $1 \mathrm{~L}$ distilled water) with an ultraturrax for $30 \mathrm{~s}$, and $2 \mathrm{~mL}$ of the resulting suspension was pipetted into $14.5 \mathrm{~cm}$ sterile petri plates in three replications. About $50 \mathrm{~mL}$ of autoclaved Fusarium selective medium, Nash and Snyder medium (15 g Peptone, $1 \mathrm{~g} \mathrm{KH}_{2} \mathrm{PO}_{4}, 0.5 \mathrm{~g} \mathrm{MgSO}_{4} .7 \mathrm{H}_{2} \mathrm{O}, 750 \mathrm{mg}$ PCNB (Pentachloronitrobenzene), and $20 \mathrm{~g}$ agar to $1 \mathrm{~L}$ distilled water) [23], was poured into each of the petri plate. The plates were incubated at $25 \pm 2{ }^{\circ} \mathrm{C}$ for 7 days and colony-forming units were counted. In the end, colony-forming units (CFU) were calculated per $\mathrm{g}$ of seed.

\subsection{Molecular Characterization}

\subsubsection{DNA Extraction}

Each single spore isolate was grown on PDA for seven days under dark conditions at room temperature. Approximately $100 \mathrm{mg}$ of fresh mycelium per isolate was crushed in liquid nitrogen, using a mortar and pestle. The fine powder of mycelium was transferred to a $2 \mathrm{~mL}$ microcentrifuge tube and genomic DNA was extracted using the DNeasy Plant Mini Kit (Qiagen Inc., Valencia, CA), following the manufacturer's instructions. The quality of the extracted DNA was controlled on $0.8 \%$ agarose gel electrophoresis and the DNA was stored at $-20^{\circ} \mathrm{C}$.

\subsubsection{DNA Sequencing and Species Identification}

The elongation factor 1-alpha gene of 67 Fusarium isolates was partially sequenced using the EF-1 $\alpha$ gene primers [24] (Table 2). The PCR conditions were as follows: Initial denaturation at $94{ }^{\circ} \mathrm{C}$ for $5 \mathrm{~min}, 39$ cycles of denaturation at $94{ }^{\circ} \mathrm{C}$ for $30 \mathrm{~s}$, annealing at $60^{\circ} \mathrm{C}$ for $30 \mathrm{~s}$, and primer extension at $72{ }^{\circ} \mathrm{C}$ for $45 \mathrm{~s}$ and $72{ }^{\circ} \mathrm{C}$ for $7 \mathrm{~min}$.

Table 2. Nucleotide sequences of primers used in this study.

\begin{tabular}{cccc}
\hline Primer & Gene & Sequences & Reference \\
\hline EF-728F & EF-1 $\alpha$ & 5'-CATCGAGAAGTTCGAGAAGG-3' $^{\prime}$ & 24 \\
EF-986R & EF-1 $\alpha$ & 5'-TACTTGAAGGAACCCTTACC-3' $^{\prime}$ & 24 \\
BT3 & B-tubulin & 5'-CGTCTAGAGGTACCCATACCGGCA-3' & 25 \\
BT5 & B-tubulin & 5'-GCTCTAGACTGCTTTCTGGCAGACC-3' & 25 \\
\hline
\end{tabular}

The PCR amplification was carried out in $25 \mu \mathrm{L}$ reaction volumes mix, containing $2 \mu \mathrm{L}$ dNTP ( $2.5 \mathrm{mM}), 2.5 \mu \mathrm{L}$ of $10 \times$ PCR buffer, $0.125 \mu \mathrm{L}$ of Taq DNA polymerase $(5 \mathrm{U} / \mu \mathrm{L}), 1 \mu \mathrm{L}$ of each of the forward and reverse primers ( $25 \mathrm{pM}$ each), and $4 \mu \mathrm{L}$ of template DNA. The resulting PCR products were checked on $0.8 \%$ agarose gel to assess product quality and estimate the concentration.

The PCR amplicons were sent to GATC Biotecth AG (Konstanz, Germany) for purification of PCR products and DNA sequencing, using the same primers used for PCR amplification. Both the forward and reverse strands were sequenced. The resulting sequences of EF- $1 \alpha$ were BLAST searched with the NCBI nucleotide database [25] for molecular species identification.

Furthermore, 50 isolates representing the various EF-groups were sequenced using the $B$-tubulin gene primer [26]. PCR conditions for the B-tubulin gene were set as follows: Initial denaturation at $94{ }^{\circ} \mathrm{C}$ for $5 \mathrm{~min}$, followed by 39 cycles of denaturation at $94{ }^{\circ} \mathrm{C}$ for $30 \mathrm{~s}$, annealing at $55^{\circ} \mathrm{C}$ for $30 \mathrm{~s}$, and primer extension at $72{ }^{\circ} \mathrm{C}$ for $1 \mathrm{~min}$ and $72{ }^{\circ} \mathrm{C}$ for $7 \mathrm{~min}$. PCR amplifications, DNA sequencing, and BLAST searching of sequences in the GenBank data base were carried out following the methods described above (for EF-1 $\alpha$ ). Sequences representing the various phylogenetic groups have been deposited in the GenBank (Table 3). 
Table 3. GenBank accession numbers of Fusarium species test isolates, representing the different phylogenetic groups.

\begin{tabular}{|c|c|c|c|c|c|c|c|}
\hline \multirow{2}{*}{ Isolate } & \multirow{2}{*}{ Host } & \multicolumn{2}{|c|}{ Gene Bank Accession Number } & \multirow{2}{*}{ Isolate } & \multirow{2}{*}{ Host } & \multicolumn{2}{|c|}{ Gene Bank Accession Number } \\
\hline & & $\mathrm{EF}-1 \alpha$ & B-tubulin & & & EF-1 $\alpha$ & B-tubulin \\
\hline 2 & F. millet & MH765585 & MH748458 & 63 & Sorghum & MH765627 & NA \\
\hline 6 & F. millet & MH765586 & MH748461 & 64 & Sorghum & MH765628 & MH748496 \\
\hline 9 & F. millet & MH765587 & MH748463 & 65 & F. millet & MH765629 & MH748497 \\
\hline 10 & Sorghum & MH765588 & MH748464 & 68 & Sorghum & MH784424 & MH748500 \\
\hline 12 & Sorghum & MH765589 & NA & 69 & Sorghum & MH784425 & MH748501 \\
\hline 13 & Sorghum & MH765590 & NA & 70 & Sorghum & MH784426 & MH748502 \\
\hline 15 & F. millet & MH765592 & NA & 71 & Sorghum & MH784427 & MH748503 \\
\hline 16 & Sorghum & MH765593 & NA & 72 & Sorghum & MH784428 & MH748504 \\
\hline 17 & Sorghum & MH765594 & NA & 73 & Sorghum & MH784429 & MH748505 \\
\hline 18 & F. millet & MH765595 & MH748465 & 74 & Sorghum & MH784430 & MH748506 \\
\hline 19 & F. millet & MH765596 & MH748466 & 76 & Sorghum & MH784431 & MH748507 \\
\hline 20 & Sorghum & MH765597 & MH748467 & 77 & Sorghum & MH784432 & MH748508 \\
\hline 21 & F. millet & MH765598 & MH748468 & 78 & Sorghum & MH784433 & MH748509 \\
\hline 25 & Sorghum & MH765600 & MH748469 & 83 & Sorghum & MH784434 & MH748514 \\
\hline 26 & F. millet & MH765601 & MH748470 & 87 & F. millet & MH784435 & MH748517 \\
\hline 27 & F. millet & MH765602 & MH748471 & 90 & Sorghum & MH784436 & MH748518 \\
\hline 29 & F. millet & MH765603 & MH748472 & 91 & Sorghum & MH765634 & NA \\
\hline 30 & Sorghum & MH784416 & MH748473 & 92 & Sorghum & MH765635 & NA \\
\hline 31 & Sorghum & MH784417 & MH748474 & 95 & Sorghum & MH765636 & MH748520 \\
\hline 33 & F. millet & MH765605 & MH748475 & 96 & Sorghum & MH784437 & MH748521 \\
\hline 34 & F. millet & MH765606 & MH748476 & & & & \\
\hline 35 & F. millet & MH784418 & MH748477 & & & & \\
\hline 36 & F. millet & MH765607 & MH748478 & & & & \\
\hline 37 & F. millet & MH765608 & MH748479 & & & & \\
\hline 38 & Sorghum & MH765609 & MH748480 & & & & \\
\hline 39 & Sorghum & MH765610 & NA & & & & \\
\hline 40 & F. millet & MH765611 & NA & & & & \\
\hline 41 & Sorghum & MH765612 & MH748481 & & & & \\
\hline 42 & Sorghum & MH765613 & MH748482 & & & & \\
\hline 43 & F. millet & MH765614 & MH748483 & & & & \\
\hline 44 & F. millet & MH765615 & MH748484 & & & & \\
\hline 45 & F. millet & MH765616 & MH748485 & & & & \\
\hline 46 & Sorghum & MH765617 & NA & & & & \\
\hline 47 & Sorghum & MH784419 & MH748486 & & & & \\
\hline 48 & F. millet & MH765618 & MH748487 & & & & \\
\hline 49 & Sorghum & MH784420 & MH748488 & & & & \\
\hline 51 & Sorghum & MH784421 & MH748490 & & & & \\
\hline 52 & Sorghum & MH765619 & MH748491 & & & & \\
\hline 53 & Sorghum & MH765620 & MH748492 & & & & \\
\hline 54 & Sorghum & MH784422 & MH748493 & & & & \\
\hline 55 & Sorghum & MH784423 & MH748494 & & & & \\
\hline 56 & Sorghum & MH765621 & NA & & & & \\
\hline 57 & Sorghum & MH765622 & NA & & & & \\
\hline 58 & Sorghum & MH765623 & NA & & & & \\
\hline 60 & Sorghum & MH765624 & NA & & & & \\
\hline 61 & Sorghum & MH765625 & NA & & & & \\
\hline 62 & Sorghum & MH765626 & NA & & & & \\
\hline
\end{tabular}

\subsubsection{Phylogenetic Analysis}

DNA sequences from the present study were aligned with reference sequences obtained from GenBank, using the multiple alignment program, Clustal W [27], and the resulting alignment was manually edited.

Phylogenetic analyses were carried out using the Maximum Likelihood method of the MEGA program version 7.0 [28] on the individual sequences of EF-1 $\alpha$ and B-tubulin genes. The same method was also used to assess the molecular phylogeny of the genus Fusarium in previous studies, e.g., [29]. For constructing the trees, sequences of the corresponding genes from the database were retrieved 
for as many reference strains as possible. Then, the reference strains that were distant from our test isolates in terms of the phylogenetic resemblance (based on sequence similarity) were excluded and closely related reference strains were included. The closest phylogenetic neighbours to the entire test isolates were retrieved from the NCBI database for the phylogenetic analysis. Statistical significance of the obtained tree was determined by running 5000 bootstrap replications.

\section{Results and Discussion}

\subsection{Grain Contamination by Fusarium Species}

All the sorghum grain samples were contaminated with Fusarium species, while the contamination frequency of finger millet grain samples varied from $44.4 \%$ in Central Ethiopia to $60 \%$ in the South region. Marked variations were also evident in terms of CFU among the samples (Table 4).

Table 4. Contamination of sorghum and finger millet grains with Fusarium species.

\begin{tabular}{ccccccc}
\hline \multirow{2}{*}{ Region } & \multicolumn{5}{c}{ CFU/g Seed of Positive Samples } \\
\cline { 2 - 7 } & Range & Mean & Median & Range & Mean & Median \\
\cline { 2 - 7 } & $250-753$ & 528.4 & 524.5 & $100-442$ & 285 & 312 \\
South & $241-558$ & 352.7 & 306 & $230-500$ & 370 & 375 \\
Central & $612-1085$ & 843.4 & 865 & $200-780$ & 473.3 & 450 \\
Northwest & 6105 &
\end{tabular}

Current results also revealed the contamination of sorghum and finger millet grains by other fungi, i.e., Aspegillus, Alternaria, Penicillium, Rhizopus, and Epicochum species, which is in line with previous findings in which cereal grains were found to be contaminated by a multitude of fungi [30,31]. On average, Fusarium load was the highest ( $843 \mathrm{CFU} / \mathrm{g})$ in sorghum grains from Northwest Ethiopia, followed by sorghum grains from South and finger millet grains from Northwest Ethiopia. This could have resulted from the more humid and warm weather conditions in the region, which favor fungal growth and grain contamination. Finger millet grains from Southern Ethiopia had the lowest average Fusarium load as compared to the other samples. These results are in agreement with those of previous reports, e.g., [32], in which sorghum was reported to be more likely to be contaminated by fungi than millets and maize. A study in the United States has also reported a mild contamination of another millet type (pearl millet, Pennisetum glaucum (L.) R. Br.), [33], suggesting the possibility that these small cereals might be less prone to fungal contamination as compared to other cereals. We have also seen that wheat grains are least contaminated by toxigenic fungi and associated mycotoxins as compared to sorghum and finger millet grains.However, the exact mechanisms of resistance in these crops should be investigated further.

\subsection{Morphological Identification}

All the Fusarium isolates included in the current study fulfilled the morphological characteristics of the genus Fusarium [23]. Based on conidial shape, 41 Fusarium isolates analysed in the current study were categorised as members of the species complex Fusarium fujikuroi, while 23 isolates were grouped within the Fusarium incarnatum-equiseti species complex and three within the Fusarium oxysporium species complex.

Although cultural/morphological characterizations provide a basis for both inter- and intra-species diversity studies, they may be unstable, highly influenced by the growth environments, and rather change with the age of the colonies [34-36]. Fusarium species delimitations by morphological features alone have also been hampered by the limited variability within such markers [37]. As a result, such taxonomic features need to be supplemented with other characters like molecular markers as reported in previous works, e.g., [38]. 


\subsection{Phylogenetic Inference}

Sequencing of the elongation factor 1-alpha (EF-1 $\alpha)$ gene was used for species identification and results were supplemented with the $\beta$-tubulin gene sequencing. EF- $1 \alpha$ has been recommended as a primary marker for the identification of Fusarium isolates to a species level $[9,38]$.

PCR amplification of the EF- $1 \alpha$ gene was positive for all the 67 Fusarium isolates, while only 50 of the isolates had positive PCR amplification for the $ß$-tubulin gene primers used in the current experiment. Seventeen isolates, all of which were identified as F. andiyazi (based on EF-1 gene sequence analysis), were not amplified by the $B$-tubulin gene primer set implemented for others. This might be because of the differences in the of $B$-tubulin gene within the genome of Fusarium species. To better understand the relationship between the species, phylogenetic trees were constructed for each locus separately [38]. Different genes within the genus Fusarium may have different evolutionary histories [29]. As a result, separate analysis of each gene would be appropriate.

Based on sequencing of the EF- $1 \alpha$ of 67 isolates, the fusaria were categorized into eight species, distributed across five main and 13 sub-clusters (Figure 1 ). The $\beta$-tubulin gene tree produced three main clusters with seven sub-clusters. Nevertheless, grouping of the Fusarium isolates by both the EF- $1 \alpha$ and B-tubulin genes in the current experiment showed a very high level of concordance. Furthermore, main and sub clusters of both trees had high bootstrap values $(>70 \%)$, confirming the highly significant association between isolates within each group/sub-group. The recovery of diverse Fusarium species in the current experiment could be attributed to the existence of various host genotypes and widely ranging environmental conditions in sorghum- and finger millet-producing regions of the country. Such diversity should be considered in future breeding programs to achieve effective and sustainable fungal and mycotoxin management strategy.

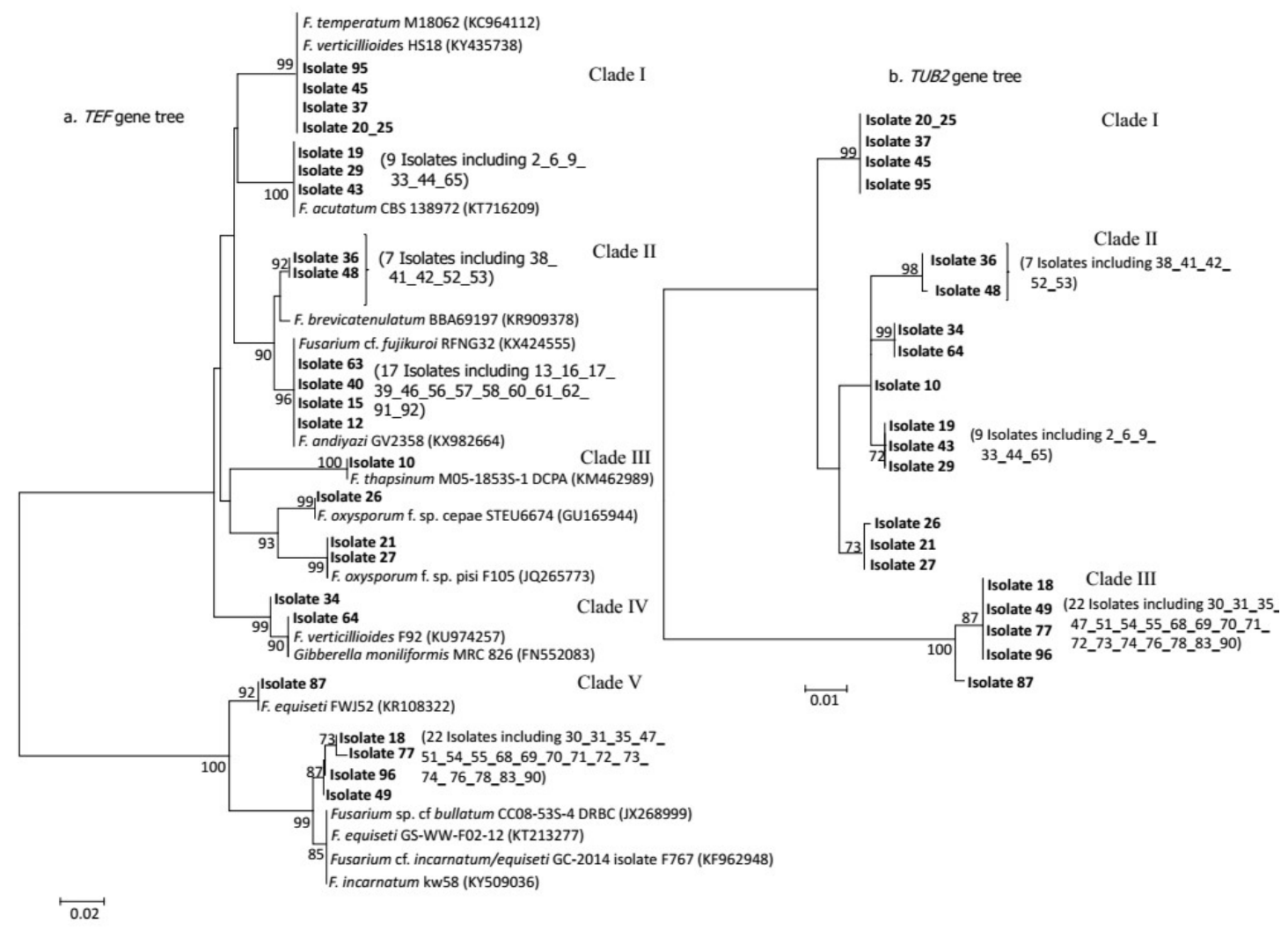

Figure 1. Maximum Likelihood phylogenetic tree showing the diversity of Fusarium isolates associated with sorghum and finger millet grains from Ethiopia. (Closely related Fusarium species from the NCBI GenBank sequences were included on the EF- $1 \alpha$ gene tree for comparison purposes). Bootstrap values (5000 replications) are shown on the branches. 
Cluster I of the EF- $1 \alpha$ gene tree contained a total of 14 isolates in two sub-groups. The first sub-group had five isolates that clustered together with $F$. verticillioides. These isolates had $100 \%$ sequence similarity with that of F. verticillioides isolates deposited in the GenBank. F. verticillioides is a cosmopolitan pathogenic fungus infecting maize stalks and grains worldwide [23]. The fungus was identified as the most dominant species associated with maize grains from Ethiopia [39]. Its identification from sorghum (three isolates) and finger millet (two isolates) grains in the present study may reveal a wider host range of the species or its variant/s. The remaining nine isolates that make up $13 \%$ of the total Fusarium isolates included in the present study occupied the second sub-group of main group I, along with $F$. acutatum on the EF- $1 \alpha$ gene tree, and the fourth sub-group of main group II on the B-tubulin gene tree. All of these nine isolates were isolated from finger millet grains from Northwest Ethiopia and they had $100 \% \mathrm{EF}-1 \alpha$ sequence similarity with several isolates of F. acutatum in the NCBI GenBank. F. acutatum has been earlier described [40]. In a later study, the same species was recovered from sesame seeds in Egypt [41]. However, the present study could be the first to report this species from finger millet grains in Ethiopia.

Cluster II of the EF-1 $\alpha$ gene tree consisted of 24 isolates belonging to F. brevicatenulatum and F.andiyazi. This cluster was further divided into two sub-clusters. The first sub-cluster is made of seven isolates ( $10 \%$ of all the isolates in the present study) that formed the same clade, thus showing $100 \%$ sequence similarity with F. brevicatenulatum. F. brevicatenulatum was first described in 1998 [42] and it was recovered from the parasitic weed (Striga asiatica) from Madagascar and from millets in east Africa $[23,43]$. In our study, isolates that belong to this species were recovered from grains of sorghum and finger millet collected from south and northwest Ethiopia. The same isolates occupied the first sub-cluster of main cluster II of the B-tubulin gene tree.

The second sub-cluster of cluster II on the EF- $1 \alpha$ gene tree was made of $17(25 \%)$ of the total Fusarium isolates from the present study. They were identified as F. andiyazi, a species that was first described in 2001 [37]. This species was subsequently reported to be present in different parts of the world, including Australia, Ethiopia, Nigeria, South Africa, and the United States [16,23,37,44]. Nevertheless, except for the initial report, no further work has been done on this particular species in Ethiopia to the best of our knowledge. As a result, the diversity of this pathogen remains largely unknown to date. The Fusarium isolates that clustered with $F$. andiyazi formed the second sub-group of main group II on the EF- $1 \alpha$ gene tree with a bootstrap value of $96 \%$. However, none of these isolates were amplified by $\beta$-tubulin gene primers (both forward and reverse), though we exhaustively tried different PCR conditions to amplify the target gene.

Cluster III of the EF- $1 \alpha$ gene tree is made of four isolates, distributed along three sub-clusters. Sub-cluster I consists of one isolate, along with an isolate of Fusarium thapsinum with $100 \%$ bootstrap. This isolate also formed its own independent sub-cluster within cluster II of the B-tubulin gene tree. Based on the EF- $1 \alpha$ gene, sub-clusters II and III had one and two isolates, respectively, which were grouped along with F. oxysporium with high bootstrap value (93\%). These three isolates formed the fifth sub-cluster of cluster II of the B-tubulin gene with high bootstrap value (73\%). All the four Fusarium test isolates within cluster III had $100 \%$ sequence similarity with isolates of the respective species in the GenBank. Fusarium thapsinum was first described in 1997 [45] and was associated with sorghum $[41,46,47]$. The isolate of $F$. thapsinum in our study was recovered from sorghum grains from South Ethiopia. On the other hand, F. oxysporium is generally believed to be a vascular wilt pathogen, commonly occurring within the soils, roots, and stems of diverse plants. However, isolates representing this species were recovered from finger millet grains in the present study and from maize, sorghum, and lentil seed from Egypt [41]. Two Fusarium isolates (34 and 64) formed cluster IV of the EF-1 $\alpha$ gene tree and they were grouped with isolates of F. verticillioides. Both isolates also had $100 \%$ EF- $1 \alpha$ sequence similarity with that of several isolates of F. verticillioides in the GenBank. On the B-tubulin gene tree, these two isolates formed their own sub-cluster within the main cluster of other isolates from the F. fujikuroi species complex. 
Cluster V has 23 isolates that belong to the F. incarnatum-equiseti species complex in three sub-clusters. This group was clearly separated from the rest with $100 \%$ bootstrap value. The first sub-cluster contains a single isolate, which had $100 \%$ EF- $1 \alpha$ sequence similarity with that of F. equiseti. This isolate also clustered with an isolate of the same species from the NCBI data base. The remaining two sub-clusters are made of 22 isolates that are clustered along with various strains of the F. incarnatum-equiseti species complex. These isolates had $98-99 \%$ sequence similarity with various known and unknown species of the species complex like F. equiseti, Fusarium sp. (FIESC), Fusarium cf. incarnatum/equiseti, Fusarium sp. cf bullatum, and F. incarnatum. Accordingly, the isolates were identified as members of the F. incarnatum-equiseti species complex. However, these isolates exhibited certain morphological distinctions from those of the other members of the species complex (F. incarnatum and F. equiseti). As a result, they were suggested to represent a novel species (Fusarium sp. nov) within the complex. With 22 (33\% of the total) isolates, the novel species was the single most dominant Fusarium species of all in the present study. They were recovered from sorghum (20 isolates) and finger millet (two isolates) grains from the south and northwest Ethiopia. Isolates belonging to this species complex were identified from various crops across a range of environmental conditions [48]. Similar isolates were also obtained from stalks of sorghum, grown in South Ethiopia in an earlier report [49], suggesting a wider geographic distribution and a lack of specificity in host colonization. On the B-tubulin gene tree, isolates of the novel species also clustered together with $87 \%$ bootstrap value and were clearly separated (100\% bootstrap) from all other isolates, except one that belonged to F. equiseti. Thus, both the EF- $1 \alpha$ and $\beta$-tubulin gene trees were in agreement that all the novel isolates belonged to the same species/group, regardless of their hosts and geographic origin. These isolates also lacked phenotypic variations, in terms of conidial shape, growth rate, and pigmentation (data not shown). Such results further strengthen the possibility that they all belong to a single species. Farmers in different regions of Ethiopia are engaged in formal and informal seed exchanges, and these could have led to the spread of the novel isolates across geographic regions.

Results of the current work reveal the phylogeny of Fusarium species associated with sorghum and finger millet grains in Ethiopia, a country considered to be one of the major centers of origin and diversity for the two crops. Current results serve as important additions to the existing knowledge on the genetic diversity of the genus Fusarium. Many of the isolates recovered in the current work are in clades with species known to produce mycotoxins. Therefore, further research should be conducted to assess the contamination of grains by mycotoxins and determine whether the isolates are toxigenic. Species description within the genus Fusarium is best accomplished by combining morphological and biological traits in addition to phylogenetic studies based on DNA sequences [50]. Future research on morpho-genetic and biological description should be undertaken to assign a taxonomic placement for isolates belonging to the novel group detected in the current work. Such studies should include the sequencing of multiple genes [43,51], studies on sexuality and fertility of the isolates [52], pathogenicity, and morpho-genetic divergence within the species. The recovery of novel isolates from grains in the current experiment and stalks in a previous work [49] may indicate that the fungus could over-season in both parts of the host plants. As a result, use of healthy seeds and removal of crop residues should be considered as important parts of managing the fungus in agricultural fields.

Author Contributions: Conceptualization, A.C.; Data curation, A.C. and T.D.; Formal analysis, A.C. and T.D.; Funding acquisition, A.C. and M.B.B.; Investigation, A.C.; Methodology, A.C., T.D. and M.B.B.; Project administration, A.C.; Resources, A.C. and M.B.B.; Software, A.C. and T.D.; Supervision, M.B.B.; Validation, A.C. and T.D.; Visualization, A.C. and T.D.; Writing—original draft, A.C.; Writing—review and editing, A.C., T.D. and M.B.B.

Funding: This work was supported by the Norwegian Agency for Development Cooperation (NORAD) through a project entitled "Research and capacity building in climate smart agriculture in the Horn of Africa" (grant number: ETH-13/0016).

Acknowledgments: The authors thank Alemayehu Getachew, Monika Skogen, Jafar Razzaghian, Belachew Asalf, and Abdelhamid Elameen for their contribution at various stages of the study.

Conflicts of Interest: The authors declare no conflict of interest as far as this work is concerned. 


\section{References}

1. Antonia, S. The Occurrence and Biology of Some Fusarium spp., on Wheat in Slovakia; Institute of Experimental Phytopathology and Entomology, Slovak Academy of Sciences: Ivanka pri Dunaji, Slovakia, 1995; 119p.

2. Brandfass, C.; Karlovsky, P. Upscaled CTAB-Based DNA Extraction and Real-Time PCR Assays for Fusarium culmorum and F. graminearum DNA in Plant Material with Reduced Sampling Error. Int. J. Mol. Sci. 2008, 9, 2306-2321. [CrossRef] [PubMed]

3. Parry, D.W.; Jenkinson, P.; Mc Leod, L. Fusarium ear blight (scab) in small grain cereals-A review. Plant Pathol. 1995, 44, 207-238. [CrossRef]

4. Bryden, W.L. Mycotoxin contamination of the feed supply chain: Implications for animal productivity and feed security. Anim. Feed Sci. Technol. 2012, 173, 134-158. [CrossRef]

5. Pestka, J.J.; Smolinski, A.T. Deoxynivalenol: Toxicology and potential effects on humans. J. Toxcol. Environ. Health Part B 2005, 8, 39-69. [CrossRef] [PubMed]

6. Wu, F.; Groopman, J.D.; Pestka, J.J. Public health impacts of foodborne mycotoxins. Ann. Rev. Food Sci. Technol. 2014, 5, 351-372. [CrossRef] [PubMed]

7. Backhouse, D.; Burgess, L.W.; Summerell, B.A. Biogeography of Fusarium. In Fusarium; Summerell, B.A., Leslie, J.F., Backhouse, D., Bryden, W., Burgess, L.W., Eds.; The American Phytopathology Society: St. Paul, MN, USA, 2001; pp. 122-137.

8. Summerell, B.A.; Laurence, M.H.; Liew, E.C.Y.; Leslie, J.F. Biogeography and phylogeography of Fusarium: A review. Fungal Divers. 2010, 44,1-11. [CrossRef]

9. Geiser, D.M.; del Mar Jiménez-Gasco, M.; Kang, S.; Makalowska, I.; Veeraraghavan, N.; Ward, T.J.; Zhang, N.; Kuldau, G.A.; O'donnell, K. FUSARIUM-ID v. 1.0: A DNA Sequence Database for Identifying Fusarium. Eur. J. Plant Pathol. 2004, 110, 473-479. [CrossRef]

10. Stukenbrock, E.H.; McDonald, B.A. Population genetics for fungal and oomycete effectors involved in gene-for-gene interactions. Mol. Plant-Microbe Interact. 2009, 22, 371-380. [CrossRef]

11. Laurence, M.H.; Walsh, J.L.; Shuttleworth, L.A.; Robinson, D.M.; Johansen, R.M.; Petrovic, T.; Vu, T.T.H.; Burgess, L.W.; Summerell, B.A.; Liew, E.C.Y. Six novel species of Fusarium from natural ecosystems in Australia. Fungal Div. 2016, 77, 349-366. [CrossRef]

12. Leavitt, S.D.; Esslinger, T.L.; Spribille, T.; Divakar, P.K.; Thorsten, L.H. Multilocus phylogeny of the lichen-forming fungal genus Melanohalea (Parmeliaceae, Ascomycota): Insights on diversity, distributions, and a comparison of species tree and concatenated topologies. Mol. Phylogenet. Evol. 2013, 66, 138-152. [CrossRef]

13. McDonald, M.C.; Razavi, M.; Friesen, T.L.; Brunner, P.C.; McDonald, B.A. Phylogenetic and population genetic analyses of Phaeosphaeria nodorum and its close relatives indicate cryptic species and an origin in the fertile crescent. Fungal Genet. Biol. 2012, 49, 882-895. [CrossRef] [PubMed]

14. O’Donnell, K.; Ward, T.J.; Geiser, G.M.; Corby, K.H.; Aoki, T. Genealogical concordance between the mating type locus and seven other nuclear genes supports formal recognition of nine phylogenetically distinct species within the Fusarium graminearum clade. Fungal Genet. Biol. 2004, 41, 600-623. [CrossRef] [PubMed]

15. Wollenweber, H.W.; Reinking, O.A. Die Fusarien, ihre Beschreibung, Schadwirkung und Bekämpfung; Paul Parey: Berlin, Germany, 1935.

16. Leslie, J.F.; Zeller, K.A.; Lamprecht, S.C.; Rheeder, J.P.; Marasas, W.F.O. Toxicity, pathogenicity, and genetic differentiation of five species of Fusarium from sorghum and millet. Phytopathology 2005, 95, $275-283$. [CrossRef] [PubMed]

17. CSA-Central Statistical Agency. Agricultural Sampling Survey. Report on Area and Production of Crops; 2016. Available online: http://www.csa.gov.et (accessed on 26 February 2017).

18. Ayalew, A.; Fehrmann, H.; Lepschy, J.; Beck, R.; Abate, D. Natural occurrence of mycotoxins in staple cereals from Ethiopia. Mycopathologia 2006, 162, 57-63. [CrossRef] [PubMed]

19. Chala, A.; Taye, W.; Ayalew, A.; Krska, R.; Sulyok, M.; Logrieco, A. Multimycotoxin analysis of sorghum (Sorghum bicolor L. Moench) and finger millet (Eleusine coracana L. Garten) from Ethiopia. Food Control 2014, 45, 29-35. [CrossRef]

20. Dejene, M. Grain Storage Methods and Their Effects on Sorghum Grain Quality in Hararghe, Ethiopia. Ph.D. Thesis, Swedish University of Agricultural Sciences (SLU), Uppsala, Sweden, 2004. 
21. Taye, W.; Ayalew, A.; Chala, A.; Dejene, M. Aflatoxin B1 and total fumonisin contamination and their producing fungi in fresh and stored sorghum grain in East Hararghe, Ethiopia. Food Addit. Contam. Part B 2016, 9, 237-245. [CrossRef]

22. Taye, W.; Ayalew, A.; Dejene, M.; Chala, A. Fungal invasion and mycotoxin contamination of stored sorghum grain as influenced by threshing methods. Int. J. Pest Manag. 2018, 64, 66-76. [CrossRef]

23. Leslie, J.F.; Summerell, B.A. The Fusarium Laboratory Manual; Blackwell: Ames, IA, USA, 2006.

24. Carbone, I.; Kohn, L.M. A method for designing primer sets for speciation studies in filamentous ascomycetes. Mycologia 1999, 91, 553-556. [CrossRef]

25. NCBI-National Center for Biotechnology Information. Available online: http://www.ncbi.nlm.nih.gov/blast/ index.shtml (accessed on 26 February 2017).

26. Tooley, P.W.; Goley, E.D.; Carras, M.M.; Frederick, R.D.; Weber, E.L. Characterization of Cleviceps species pathogenic on sorghum by sequence analysis of the $\beta$-tubulin gene intron 3 region and EF- $1 \alpha$ gene intron 4 . Mycologia 2001, 93, 541-551.

27. Thompson, J.D.; Higgins, D.G.; Gibson, T.J. Clustal W: Improving the sensitivity of progressive multiple sequence alignment through sequence weighting, position specific gap penalties and weight matrix choice. Nucleic Acids Res. 1994, 22, 4673-4680. [CrossRef]

28. Kumar, S.; Stecher, G.; Tamura, K. MEGA7: Molecular evolutionary genetics analysis version 7.0 for bigger datasets. Mol. Biol. Evol. 2016, 33, 1870-1874. [CrossRef] [PubMed]

29. Watanabe, M.; Yonezawa, T.; Lee, K.; Kumagai, S.; Sugita-Konishi, Y.; Goto, K.; Hara-Kudo, Y. Molecular phylogeny of the higher and lower taxonomy of the Fusarium genus and differences in the evolutionary histories of multiple genes. BMC Evol. Biol. 2011, 11, 322. [CrossRef] [PubMed]

30. Atehnkeng, J.; Ojiambo, P.; Donner, M.; Ikotun, T.; Sikora, R.; Cotty, P.; Bandyopadhyay, R. Distribution and toxigenicity of Aspergillus species isolated from maize kernels from three agro-ecological zones in Nigeria. Int. J. Food Microbiol. 2008, 122, 74-84. [CrossRef] [PubMed]

31. Logrieco, A.; Rizzo, A.; Ferracane, R.; Ritieni, A. Occurrence of Beauvericin and Enniatins in Wheat Affected by Fusarium avenaceum Head Blight. Appl. Environ. Microbiol. 2002, 68, 82-85. [CrossRef] [PubMed]

32. Bandyopadhyay, R.; Kumar, M.; Leslie, J.F. Relative severity of aflatoxin contamination of cereal crops in West Africa. Food Addit. Contam. 2007, 24, 1109-1114. [CrossRef] [PubMed]

33. Wilson, J.P.; Jurjevic, J.; Hanna, W.W.; Wilson, D.M.; Potter, T.L.; Coy, A.E. Host-specific variation in infection by toxigenic fungi and contamination by mycotoxins in pearl millet and corn. Mycopathologia 2006, 161, 101-107. [CrossRef] [PubMed]

34. Browning, M.; Rowley, L.V.; Zang, P.; Chandlee, J.M.; Jackson, N. Morphological, pathogenic and genetic comparisons of Colletotrichum graminicola isolates from Poaceae. Plant Dis. 1999, 83, 286-292. [CrossRef] [PubMed]

35. Crouch, J.A.; Clarke, B.B.; Hillman, B.I. Unraveling evolutionary relationships among divergent lineages of Colletotrichum causing anthracnose disease in turfgrass and corn. Phytopathology 2006, 96, 46-60. [CrossRef] [PubMed]

36. Rivera-Vargas, L.I.; Lugo-Noel, Y.; McGovern, R.J.; Seijo, T.; Davis, M.J. Occurrence and distribution of Colletotrichum spp. on mango (Mangifera indica L.) in Puerto Rico and Florida, USA. Plant Pathol. J. 2006, 5, 191-198.

37. Marasas, W.F.O.; Rheeder, J.P.; Lamprecht, S.C.; Zeller, K.A.; Leslie, J.F. Fusarium andiyazi sp. nov., a new species from sorghum. Mycologia 2001, 93, 1203-1210. [CrossRef]

38. Al-Hatmi, A.M.S.; Mirabolfathy, M.; Hagen, F.; Normand, A.C.; Stielow, J.B.; Karami-Osbo, R.; van Diepeningen, A.D.; Meis, J.F.; de Hoog, G.S. DNA barcoding, MALDI-TOF, and AFLP data support Fusarium ficicrescens as a distinct species within the Fusarium fujikuroi species complex. Fungal Biol. 2016, 120, 265-278. [CrossRef] [PubMed]

39. Tsehaye, H.; Brurberg, M.B.; Sundheim, L.; Assefa, D.; Tronsmo, A.; Tronsmo, A.M. Natural occurrence of Fusarium species and fumonisin on maize grains in Ethiopia. Eur. J. Plant Pathol. 2017, 147, 141-155. [CrossRef]

40. Nirenberg, H.I.; O'Donnell, K. New Fusarium species and combinations within the Gibberella fujikuroi species complex. Mycologia 1998, 90, 434-458. [CrossRef] 
41. Abdel-Hafez, S.I.I.; Ismail, M.A.; Hussein, N.A.; Abdel-Hameed, N.A. Fusarium species and other fungi associated with some seeds and grains in Egypt, with 2 newly recorded Fusarium species. J. Biol. Earth Sci. 2014, 4, 120-129.

42. Nirenberg, H.I.; O’Donnell, K.; Kroschel, J.; Andrianaivo, A.P.; Frank, J.M.; Mubatanhema, W. Two new species of Fusarium: Fusarium brevincatenulatum from the noxious weed Striga asiatica in Madagascar and Fusarium pseudoanthophilum from Zea mays in Zimbabwe. Mycologia 1998, 90, 459-464. [CrossRef]

43. Amata, R.L.; Burgess, L.W.; Summerell, B.A.; Bullock, S.; Liew, E.C.Y.; Smith-White, J.L. An emended description of Fusarium brevicatenulatum and F. pseudoanthophilum based on isolates recovered from millet in Kenya. Fungal Div. 2010, 43, 11-25. [CrossRef]

44. Marley, P.; Marasas, W.F.O.; Hester, V. Occurrence of Fusarium andiyazi associated with sorghum in Nigeria. Arch. Phytopathol. Plant Prot. 2004, 37, 177-181. [CrossRef]

45. Klittich, C.J.R.; Leslie, J.F.; Nelson, P.E.; Marasas, W.F.O. Fusarium thapsinum (Gibberella thapsina): A new species in section Liseola from sorghum. Mycologia 1997, 89, 643-652. [CrossRef]

46. Frederiksen, R.A.; Odvody, G.N. Compendium of Sorghum Diseases, 2nd ed.; APS Press: St. Paul, MN, USA, 2000.

47. Jardine, D.J.; Leslie, J.F. Aggressiveness of Gibberella fujikuroi (Fusarium moniliforme) isolates to grain sorghum under greenhouse conditions. Plant Dis. 1992, 76, 897-900. [CrossRef]

48. Castellá, G.; Cabañes, F.G. Phylogenetic diversity of Fusarium incarnatum-equiseti species complex isolated from Spanish wheat. Antonie Van Leeuwenhoek 2014, 106, 309-317. [CrossRef]

49. Chala, A. Genetic diversity among Fusarium species associated with sorghum stalk rot in Southern Ethiopia. Afr. J. Biotechnol. 2019, 18, 289-295.

50. Leslie, J.F.; Zeller, K.A.; Summerell, B.A. Icebergs and species in populations of Fusarium. Physiol. Mol. Plant Pathol. 2001, 59, 107-117. [CrossRef]

51. O'Donnell, K.; Nirenberg, H.I.; Aoki, T.; Cigelnik, E. A multigene phylogeny of the Gibberella fujikuroi species complex: Detection of additional phylogenetically distinct species. Mycoscience 2000, 41, 61-78. [CrossRef]

52. Leslie, J.F.; Zeller, K.; Wohler, M.; Summerell, B.A. Interfertility of two mating populations in the Gibberella fujikuroi species complex. Eur. J. Plant Pathol. 2004, 110, 611-618. [CrossRef]

(C) 2019 by the authors. Licensee MDPI, Basel, Switzerland. This article is an open access article distributed under the terms and conditions of the Creative Commons Attribution (CC BY) license (http://creativecommons.org/licenses/by/4.0/). 